\title{
Equilibrium and Kinetics studies for Removal of Heavy Metals from simulated Wastewater using Chitosan/Activated carbon composite
}

\author{
Ahmed Saad Ali ${ }^{1 *}$, Ali Mustafa A. Hassan ${ }^{2}$, Mohammed Hamdi Nour ${ }^{3}$ \\ ${ }^{1}$ Environmental Engineering Program, School of Science and Engineering, The American University in Cairo, \\ P.O. Box 74, New Cairo 11835, Egypt \\ ${ }^{2}$ Chemistry Department, Faculty of Science, Al-Azhar University, Nasr City 11884, Cairo, Egypt \\ ${ }^{3}$ Civil Engineering Department, Faculty of Engineering, Cairo University, Giza, Egypt
}

*Corresponding Authors: Ahmed Saad Ali, Environmental Engineering Program, School of Science and Engineering, The American University in Cairo, P.O. Box 74, New Cairo 11835, Egypt

\begin{abstract}
Removal of lead, copper, and cadmium from aqueous solution with chitosan/activated carbon (CH/AC) composite was studied under batch equilibrium technique setup. The composite was prepared by blending chitosan gel with activated carbon by ratio of (3:1). The physical and chemical characters of the composite was studied by several analyses; (bulk density, BET surface area, pHpzc, SEM, and EDX). The adsorption behavior of the target metals was examined as function of $\mathrm{pH}$, contact time, sorbent dose, and initial metal concentration. Prior to the batch equilibrium experiments the metal hydroxide precipitation was studied to determine the $\mathrm{pH}$ edge of the metal precipitation. The lead hydroxide precipitation edge is $\geq 6.0$ while the copper and cadmium hydroxide precipitation is $\geq 7.0$. pHpzc experiment revealed positive surface charge of the composite at $\mathrm{pH}$ equal to 7.6 that means electrostatic attraction is not the dominant mechanism for the sorption of cations. The optimum $\mathrm{pH}$ was 5.5, 6.0 for lead and both copper and cadmium respectively. qe was $13.1 \mathrm{mg} / \mathrm{g}, 12.2 \mathrm{mg} / \mathrm{g}$, and $10.4 \mathrm{mg} / \mathrm{g}$ for copper, lead, and cadmium respectively. Adsorption isotherms for the three metals is correlated well with Langmuir type of adsorption isotherm which means that chemisorption is the dominate mechanism in the sorption process. Also, the adsorption process for the three metals were found to follow pseudo second - order type of adsorption kinetics, which revealed that the rate-limiting factor might be chemisorption involving valance forces through sharing of electrons between the amino groups of chitosan and the metal ions.
\end{abstract}

Keywords: Adsorption; Heavy Metals, Chitosan; composite; Isotherm; Kinetic

\section{INTRODUCTION}

The direct or indirect discharge of heavy metals into aquatic systems has become a matter of concern in the world over the last few decades. They have been prioritized as major inorganic contaminants in the environment because of their accumulation tendency, hazardous effect, and toxicity to the human life and environmental health [1]. Unlike the organic contaminants where the majority of which are susceptible to biological degradation into harmless end products, heavy metals are not biodegradable and tend to accumulate in living organisms causing numerous diseases and disorders [2]. The term heavy metals refers to the elements that have atomic weights between 63.5 and 200.6, and density greater than $5.0 \mathrm{gm} / \mathrm{cm}^{3}$ (e.g. $\mathrm{Ag}, \mathrm{Hg}, \mathrm{Pb}, \mathrm{Cr}, \mathrm{Cd}, \mathrm{As}, \mathrm{Al}, \mathrm{Cu} . .$. ) [3,4]. Lead, cadmium and copper are the most common toxic heavy metals in the industrial wastewater effluents [5]. The potential sources of these heavy metals in wastewater are discharge waste stream from electric batteries manufacturing, nickel/cadmium batteries, lead smelting, plumbing, glass industry, gasoline additive, ceramic and porcelain enameling, piping, electroplating, and oil/gas exploration and drilling [6-8]. The World Health Organization (WHO) guidelines values of lead, copper, and cadmium in drinking water are 0.01, 2.0, and $0.003 \mathrm{mg} / \mathrm{L}$ respectively [9]. Several remediation techniques have been employed to mitigate or remove heavy metals from wastewater. The commonly used techniques are chemical precipitation, coagulation-flocculation, phytoremediation, reverse osmosis, ion exchange, carbon adsorption, resin sorption, electro-dialysis, and adsorption [10-11]. However, most of these technologies are not ecofriendly or economically viable and have significant demerits such as hazardous sludge formation which 
convert the aquatic problem into solid problem, incomplete metal removal, and high cost at large scale [12-13]. Motivated by cost consideration, the efficiency of low cost adsorbents like agricultural wastes and seafood processing wastes is the promising alternative. Recently, a considerable attention has been focused on the biosorbents (sorbent materials with biological origin) as an efficient, low cost, and ecofriendly materials for the treatment of wastewater containing heavy metals [14]. One of such kinds is chitosan, $\beta$ - $(1 \rightarrow 4)$-linked -D- glucosamine units (deacetylated units) together with some proportion of $\mathrm{N}$-acetyl -D-glucosamine units (acetylated units), which can be produced from fishery waste by partially alkaline deacetylation of Chitin. Chitin, $\beta-(1 \rightarrow 4)$-linked-N-acetyl-D-glucosamine, is the second most abundant biopolymer next to cellulose, can be extracted commercially from the shells of crustacean (such as crabs, shrimps, prawns, krill), insects, and fungi [15-16]. Chitosan and its derivatives have been applied in different fields ranging from pharmaceutical, medicine, cosmetics to wastewater and drinking water treatment. [17-18]. Chitosan is more useful and effective biosorbent as compared to chitin, since it has unique and distinctive features like, biodegradability, nontoxicity, high reactivity, excellent chelation behavior due to the presence of amine and hydroxyl functional groups which show high adsorption potential for various aquatic pollutions, and low cost in comparison with other adsorbents. However, it cannot be used in the raw form due to the presence of undesirable characters such as low mechanical strength and poor chemical resistance like swelling and solubility in acidic solutions. Physical and chemical modifications methods have been used to modify raw chitosan. These methods include crosslinking, grafting, and blending. The modifications were proposed in order to improve pore size, mechanical strength, chemical stability, and hydrophilicity [19]. Recently, chitosan blending has become one of the effective methods for providing new desirable polymeric materials for practical applications. Different kinds of substances have been used in blending with chitosan to form composite such as activated clay, polyurethane, cotton fibers, magnetite, cellulose, perlite, ceramic alumina, calcium alginate, sand, polyvinyl chloride (PVC), polyvinyl alcohol (PVA), and activated carbon [20]. As the activated carbon has unique porous structure, high specific surface area and high mechanical and chemical resistance which will offer desirable properties to chitosan by blending with it in composite. Moreover it can be prepared from non-expensive sources such as agriculture wastes; ( e.g. cotton stalks, rice straw, coconut shells, sugar can bagasse, etc......)[21].The polymeric composite; chitosan/activated carbon $(\mathrm{CH} / \mathrm{AC})$ represents one of the environmental friendly solution by transforming the materials with negative value to valuable materials. This work aims to investigate the influence of various experimental parameters $(\mathrm{pH}$, contact time, sorbent dose, and initial metal concentration) on the sorption of lead, copper, and cadmium by $\mathrm{CH} / \mathrm{AC}$ composite as a potential and low cost sorbent. Moreover, the experimental results were evaluated using both Langmuir and Freundlich isotherm models and pseudo first order and pseudo second order kinetic models to obtain the needed parameters. To get results with good level of confidence all experiments were conducted twice and mean values were used

\section{Material AND MethodS}

\subsection{Material}

Practical grade chitosan flakes $(\mathrm{CH})$ with degree of de-acetylation $\geq 75 \%$, and molecular weight of 190-375 kilo Dalton (KDa) was purchased from Sigma-Aldrich Company. Commercial activated carbon (AC) granular shape was purchased from the local market. Stock solutions of (1000 mg/L) Lead, copper, and cadmium, were purchased from MERCK Company. Deionized distilled water (DDW) was used in the preparation of all the solutions and standards in the experiments and the analyses. $\mathrm{NaNO}_{3}$ salt (assay 99\%) manufactured by (GCC) company, United Kingdom, was used as ionic background in the metals solutions. Concentrated nitric acid and Sodium hydroxide pellets with American Chemicals Society (ACS) grade, were purchased from MERCK Company. Acetic acid with concentration 96\%, with ACS grade was purchased from Free Trade Egypt Company.

\subsection{Preparation of $\mathrm{CH} / \mathrm{AC}$ composite}

$\mathrm{CH} / \mathrm{AC}$ composite with ratio of 3:1 (CH.: AC.) was prepared according to (Hakimeh Sh. Et.al. (2012), Viorica P.; et.al. (2013), Xiaoyu Ch., and Lindun He, (2017)) [22-24] with slight modification, as the following. A 30.0 grams' amount of commercial $(\mathrm{CH}$.) flakes was dissolved in $500 \mathrm{ml}$ of $5 \%(\mathrm{v} / \mathrm{v})$ acetic acid solution under continuous stirring at $45-50^{\circ} \mathrm{C}$ until formation of $(\mathrm{CH})$ gel. About 10 grams of granular (AC) was added slowly to the $(\mathrm{CH})$ gel and stirred for 24 hours at $45-50^{\circ} \mathrm{C}$. Then, the $(\mathrm{CH} / \mathrm{AC})$ 
composite beads were prepared by injecting the $(\mathrm{CH} / \mathrm{AC})$ gel in droplets through a syringe nozzle into a $500 \mathrm{ml}$ of $0.1 \mathrm{M} \mathrm{NaOH}$ precipitation bath. The composite beads were allowed to stay in the $\mathrm{NaOH}$ precipitation bath with slow stirring for 6 hours. After that, the beads were separated from $\mathrm{NaOH}$ solution by filtration, and washed several times with deionized water to a slightly neutral $\mathrm{pH}(7.5 \pm 0.5)$. Finally, the beads were dried in air oven at $60^{\circ} \mathrm{C}$ for 24 hours, and grinded. After that, the materials were sieved, passed through Mesh No. $25(0.7 \mathrm{~mm})$ and collected on Mesh No. $35(0.5 \mathrm{~mm})$. The homogenous particles with particle sizes of $(0.5-0.6) \mathrm{mm}$ were dried and kept in desiccator prior to work.

\subsection{Characterization of $\mathrm{CH} / \mathrm{AC}$ composite}

The composite was characterized by the selected physical and chemical analyses:

\section{•Bulk density:}

To measure bulk density, a pre-weighted $10 \mathrm{ml}$ cylinder was filled to a specified volume with dried adsorbent; (the dry material was freely settled). Then the cylinder was weighted with the dry material, and the weight of the dry material was calculated as:

Weight of dry material $(\mathrm{g})=$ weight of the cylinder with the material - weight of the empty cylinder[1]

The bulk density calculated as [25]:

Bulk density =

$\frac{\text { weight of the dry material }(\mathrm{g})}{\text { volume of the dry metrial }(\mathrm{cm} 3)}$

-BET surface area:

It was determined from adsorption-desorption isotherm of nitrogen gas at $77 \mathrm{~K}$, by using a Micrometrics -ASAP 2020 surface area and porosity analyzer. Prior to the analysis, the samples were degassed at $60{ }^{\circ} \mathrm{C}$ for 4 hours under a vacuum of $10 \mathrm{um} \mathrm{Hg}$. The specific surface area was calculated using Brunauer - Emmett- Teller (BET) method, while pore volumes and average pore diameter were calculated by the Barrett- Joyner- Halenda (BJH) method.

\section{-pHpoint of zero charge (pHpzc):}

$\left(\mathbf{p} \boldsymbol{H}_{\mathbf{p z c}}\right)$ is often used to study the impact of the electrostatic surface charge of the adsorbent on the adsorption process. It is the $\mathrm{pH}$ value at which the surface charge of the material becomes equal to zero under given conditions of temperature, applied pressure, and aqueous solution. This does not mean that the surface has no charge at $(\mathrm{pHpzc})$, but rather that there are equal amounts of positive and negative charges on the surface [26]. The experiment was done by salt addition method [27] as the following: ten samples of each material with $0.1 \mathrm{~g}$ each were added into ten $125 \mathrm{ml}$ high density polyethylene (HDPE) bottles. Then, a portion of $50 \mathrm{ml} 0.01 \mathrm{M}$ purged sodium nitrate solution was added to each bottle. After that, $\mathrm{pH}$ of the solutions was adjusted to the desired $\mathrm{pH}$ values (from 2 to 11 ) using $0.1 \mathrm{M}$ $\mathrm{NaOH}$ or $0.1 \mathrm{M} \mathrm{HNO} 3$ and recorded as initial $\mathrm{pH}\left(\mathrm{pH}_{\mathrm{I}}\right)$. After 48 hours of continuous shaking on rotary shaker, with speed of 150 round per minute (rpm), the solutions were filtered, through 0.45 um cellulose nitrate membranes in plastic filtering device. The $\mathrm{pH}$ of each filtrate was measured and recorded as final $\mathrm{pH}\left(\mathrm{pH}_{\mathrm{F}}\right)$. The difference between initial $\mathrm{pH}$ and final $\mathrm{pH}$ was calculated and reported as $\Delta \mathrm{pH}$.

$\Delta \mathbf{p H}=$ final $\mathbf{p H}\left(\mathbf{p H}_{\mathrm{F}}\right)$ - initial $\mathbf{p H}\left(\mathbf{p H}_{\mathrm{I}}\right)$

The (pHpzc) would be determined by plotting $\Delta \mathrm{pH}$ against initial $\mathrm{pH}\left(\mathrm{pH}_{\mathrm{I}}\right)$. It is the point at which the curve of $\Delta \mathrm{pH}$ crosses the line of initial $\mathrm{pH}\left(\mathrm{pH}_{\mathrm{I}}\right)$

\section{SEM \& EDX analysis:}

The surface morphology of the composite before and after metals sorption was conducted by the Scanning Electron Microscope; SEM (model LEO SUPRA 55, manufactured by ZEISS company, Germany). While the elemental analysis of the composite before and after metals sorption was conducted by the Energy Dispersive X-ray; EDX unit which represents a complementary technology to the SEM. The Samples were coated by thin layer of gold prior to the analysis to be more conductor. 


\subsection{Batch equilibrium experiments}

The sorption isotherm is the ratio between the quantity adsorbed and the quantity remaining in solution under fixed temperature at equilibrium [28]. The optimum environmental factors such as initial $\mathrm{pH}$, contact time, initial composite dose, and initial metal concentration are studied in this set experiments. These factors are known with their significant effect on the sorption equilibrium. The purpose of these experiments is to determine the optimum $\mathrm{pH}$, the time of equilibrium, and the sorption capacity of the composite. The batch experiments are carried out in well-sealed $125 \mathrm{ml}$ high density polyethylene (HDPE) bottles. When these bottles agitated, they can be assumed to function as completely mixed batch reactors. The volume of each sample in the experiments was $50 \mathrm{ml}$ of synthetic wastewater solution containing $30 \mathrm{mg} / \mathrm{L}$ from the target metal and $0.1 \mathrm{M} \mathrm{NaNO}_{3}$ as ionic background to simulate the effect of the anions and the cations in the real wastewater. The desired $\mathrm{pH}$ of the samples was adjusted by $0.1 \mathrm{MNaOH}$ or $0.1 \mathrm{MHNO}_{3}$. The composite was added to all the samples except the control samples. The samples were shaked at room temperature $\left(22.0 \pm 0.5{ }^{\circ} \mathrm{C}\right)$ on the rotary shaker at 150 round per minute (r.p.m). The experiments were carried out under controlled pH. Subsequently, each sample was filtered through prewashed cellulose acetate filter paper $(0.45 \mathrm{um})$, and acidified to $\mathrm{pH}<2.0$ using 1:1 HNO3 and then analyzed by Atomic Absorption Spectrometer (AAS) model Sence AA. The percentage removal $(\% \mathrm{R})$ of each metal was calculated using the

Equation: $\quad \%$ removal $=\frac{C i-C f}{C i} \boldsymbol{x} \mathbf{1 0 0}$

The sorption capacity is obtained by using the mass balance equation:

qt $=\frac{C i-C t}{m} x V$

$\mathrm{q}_{\mathrm{e}}=\frac{C i-C f}{m} x \mathrm{~V}$

Where, $q_{t}$ and $q_{e}$ are the amounts of metal ions adsorbed at time $t$ and at equilibrium respectively in $\mathrm{mg}$ of metal per $\mathrm{g}$ of sorbent $(\mathrm{mg} / \mathrm{g}), \mathrm{C}_{\mathrm{i}}$ and $\mathrm{C}_{\mathrm{f}}$ are the initial and final metal ion concentration in $(\mathrm{mg} / \mathrm{L}), \mathrm{C}_{\mathrm{t}}$ is the concentration of metal ions at time $t, \mathrm{~V}$ is the volume of the solution in $(\mathrm{L})$, and $\mathrm{m}$ is the weight of dry sorbent ( composite) (g).

\section{-Metal Hydroxide Precipitation experiment:}

The experiment was conducted to investigate the metal hydroxide precipitation as function of $\mathrm{pH}$. It was carried out at $\mathrm{pH}$ range $(2-11)$. Each sample contains $30 \mathrm{mg} / \mathrm{L}$ from each target metal individually without composite.

\section{-Effect of pH experiment:}

Based on the previous experiment of metal hydroxide precipitation, the experiment was carried out at controlled $\mathrm{pH}$ ranges $(2.0-6.0 \pm 0.05)$ for $\mathrm{Pb}$ (II) and (2.0-7.0 \pm 0.05$)$ for both $\mathrm{Cu}$ (II) and $\mathrm{Cd}(\mathrm{II})$. $\mathrm{The}$ samples were shaked for about 5 hours.

\section{-Effect of contact time experiment:}

This experiment was carried out at time range (0-600) minutes, at the optimum pH for each target metal; (5.5 \pm 0.05 ) for $\mathrm{Pb}(\mathrm{II})$, and $6.0 \pm 0.05$ for $\mathrm{Cu}(\mathrm{II})$, and $\mathrm{Cd}$ (II).

\section{-Effect of composite dose experiment:}

The experiment was conducted with composite doses of (0.5-4.5) g/L at the optimum conditions.

\section{-Effect of initial metal concentration}

The experiment was conducted with metal concentrations of (10-200) $\mathrm{mg} / \mathrm{L}$ from each target metal.

\subsection{Sorption isotherm models}

\section{-Langmuir isotherm model:}

The Langmuir isotherm (1918) is an empirical model assumes homogenous sorption sites and sorption energies on the surface of adsorbents. Also, it assumes that, there is not any interaction between the 
adsorbed molecules (i.e. the ability of molecule to adsorb at a given site is independent on the occupation of the neighboring sites [29]. The linear form of the model is presented by the equation:

$\frac{1}{q_{e}}=\frac{1}{C_{e} q_{m} b}+\frac{1}{q_{m}}$

Where, $q_{e}(\mathrm{mg} / \mathrm{g})$ is the amount of adsorbate adsorbed per gram of adsorbent at equilibrium (adsorption capacity). $C_{e}(\mathrm{mg} / \mathrm{L})$ is the equilibrium (residual) concentration of the metal ions in the solution, $q_{m}$ ( $\mathrm{mg} / \mathrm{gm}$ ) is the maximum (ultimate) adsorption capacity, and $b$ (liter / $\mathrm{mg}$ ) is the Langmuir constant related to the binding energy of adsorption. Plotting of $\frac{1}{q_{e}}$ versus $\frac{1}{C_{e}}$ would give the Langmuir constants $\mathrm{q}_{\mathrm{m}}$ and $b$. The higher the value of $b$ the higher the affinity of the sorbent to the sorbate.

\section{-Freundlich Isotherm model:}

The Freundlich isotherm model is based on the heterogeneity. It assumes that the sorption sites have heterogeneous energy, varied strength, and work in multi-layer [30]. The linear form of the model is presented by the equation:

$$
\log q_{e}=\log K_{F}+\frac{1}{n} \log C_{e}
$$

Where, $q_{e}(\mathrm{mg} / \mathrm{g})$ is the mass of metal adsorbed per gram of adsorbent at equilibrium; (adsorption capacity), $C_{e}(\mathrm{mg} / \mathrm{liter})$ is the equilibrium of metal concentration in the solution, $K_{F}$ and $1 / \mathrm{n}$ are Freundlich isotherm constants (empirical constants). They are indicator of adsorption capacity, and adsorption intensity respectively. The smaller the value of $\frac{1}{n}$ the stronger the adsorption bonds. These constants can be obtained by plotting $\log q_{e}$

versus $\log C_{e}$

\subsection{Kinetic models}

In order to investigate the controlling mechanism of the sorption processes, the sorption rate constants, and sorption capacity, pseudo first-order and pseudo-second order kinetics were applied in the data of adsorption.

\section{-Pseudo First - Order Kinetic}

The pseudo first-order kinetics can be expressed as: $\log \left(\mathbf{q}_{\mathrm{e}}-\mathbf{q}_{\mathbf{t}}\right)=\log \mathbf{q}_{\mathrm{e}}-\frac{K 1}{2.303} t$

Where, $K_{1}$ is the rate constant of pseudo first - order adsorption $\left(\min ^{-1}\right) ; q_{e}$ and $q_{t}$ are the amount of metal ion adsorbed per gram adsorbate at equilibrium and at any time $t$ respectively $(\mathrm{mg} / \mathrm{g})$. Plotting of $\log \left(\mathbf{q}_{\mathbf{e}}-\mathbf{q}_{\mathbf{t}}\right)$ versus $\boldsymbol{t}$ would give the first - order rate constant $\boldsymbol{K}_{\mathbf{1}}$ and equilibrium adsorption capacity $\boldsymbol{q}_{\boldsymbol{e}}$ from the slope and intercept of the straight line .

\section{•Pseudo Second - Order Kinetic}

The pseudo second - order kinetics can be expressed as: $\frac{t}{q_{t}}=\frac{1}{K_{2} q_{t}^{2}}+\frac{t}{q_{t}}$

Where $\boldsymbol{K}_{\mathbf{2}}$ (g/ $\left.\mathrm{mg} \min \right)$ is the rate constant of pseudo second-order kinetic model. Plotting of $\boldsymbol{t} / \boldsymbol{q}_{\boldsymbol{t}}$ versus $\boldsymbol{t}$ would give the pseudo second - order rate constant $K_{2}$ and $\boldsymbol{q}_{\boldsymbol{e}}$.

\section{RESUltS AND DiSCUSSION}

\subsection{Characteristics Analysis.}

The bulk density, surface area, pore volume, and pore size of the composite, $\mathrm{CH}$, and $\mathrm{AC}$ are shown in Table 1. It has shown that improvement in the composite properties in comparison with $\mathrm{CH}$. Significant increase in surface area and pore volume of the composite is related to blending of it with AC. Obviously the metal uptake capacity of the composite will be higher due to the presence of more free adsorption sites. Bulk density of the adsorbent material has an effect on its adsorption efficiency and the performance of the adsorption process [31]. The moderate value of Bulk density of the composite in comparison with $\mathrm{CH}$ and $\mathrm{AC}$ gives it desirable character in adsorption efficiency and adsorption performance in the treatment plants. The average pore diameter of the composite particles indicates that, the material of the composite is mesoporous material, according to International Union of pure and 
applied Chemistry (IUPAC) classification. among different porous materials, mesoporous material is most favorable in aqueous system, as they have moderate diffusion flux and highly efficient mass transfer are achievable due to their appropriate pore dimension, high specific surface area and good organic adsorption capacity [32]. - In order to understand the sorption mechanism, it is necessary to determine the zero charge point (pHpzc) of the adsorbent material, as it indicates how easily the adsorptive materials are able to adsorb the ions of target pollutants [33]. The pHpzc value of composite is about 7.6; (higher than the optimum $\mathrm{pH}$ value of $\mathrm{Pb}$ (II), $\mathrm{Cu}$ (II), and $\mathrm{Cd}$ (II), as shown in the next part of study). This

Table1: Physical characteristics of $C H / A C$ composite, commercial $\mathrm{CH}$, and $\mathrm{AC}$.

\begin{tabular}{|l|l|l|l|}
\hline Parameter & composite & CH. & AC. \\
\hline Bulk density $\left(\mathrm{g} / \mathrm{cm}^{3}\right)$ & 0.32 & 0.198 & 0.5007 \\
\hline pHpzc & 7.6 & 5.95 & 8.36 \\
\hline BET surface area & 287.352 & 0.543 & 773.7 \\
\hline Total pore volume $(\mathrm{cm} 3 / \mathrm{g})$ & 0.160 & 0.001 & 0.417 \\
\hline Average pore diameter $(\mathrm{nm})$ & 2.232 & 10.97 & 2.156 \\
\hline
\end{tabular}

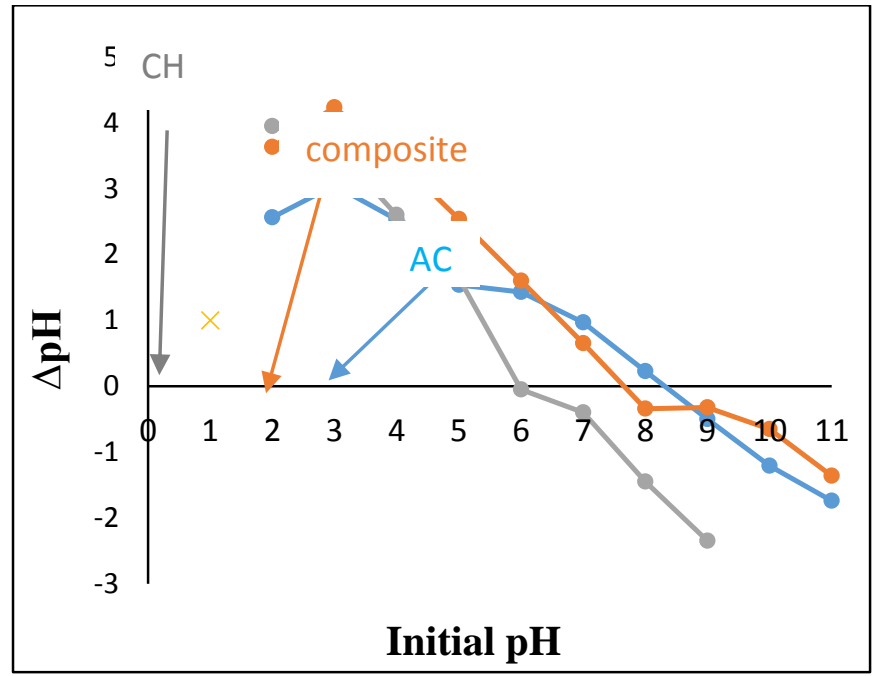

Figure1: $p H$ point of zero charge ( $p H p z c$ ) of composite, $\mathrm{CH}$, and $A C$.

revealed that the electrostatic interaction (physisorption) between the metal ions $\mathrm{M}^{+}$and the surface of the composite could be hard, and other mechanism (chemisorption) could be work as a dominant mechanism between $\mathrm{M}^{+}$ions and the active groups on the composite surface.

\section{$\underline{S E M \& E D X \text { analysis }}$}

Figures 2 and 3 displays the presence of pores and cracks on the surface of composite confirming the higher surface area of it, while the surface of chitosan has relative smooth structure confirming its low pore volume and surface area.

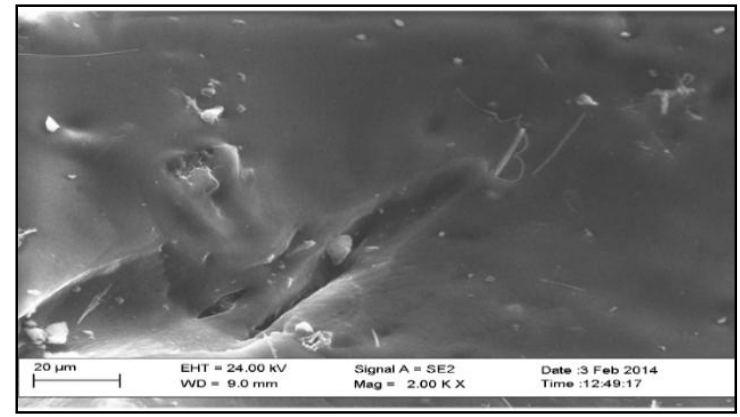

Figure2. SEM micrographs of chitosan 


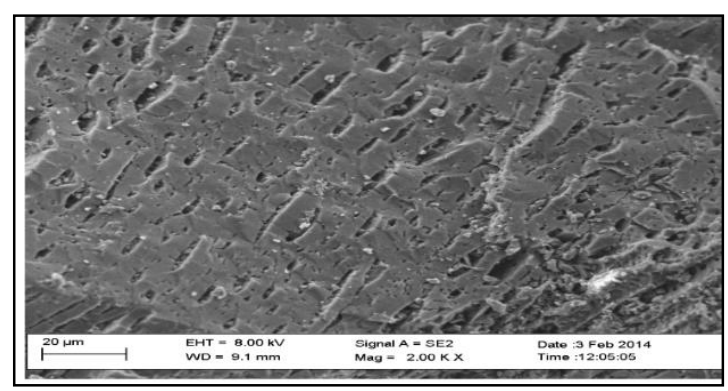

Figure3. SEM micrographs of composite

Table2: EDX analysis of raw composite

\begin{tabular}{|l|c|c|}
\hline \multicolumn{1}{|c|}{ Element } & Wt.\% & At. \% \\
\hline N K & 8.34 & 10.38 \\
\hline O K & 73.94 & 80.54 \\
\hline Al K & 9.93 & 6.42 \\
\hline Ca K & 5.26 & 2.29 \\
\hline Fe K & 0.72 & 0.22 \\
\hline Au M & 1.81 & 0.16 \\
\hline Totals & 100 & \\
\hline
\end{tabular}

Table3: EDX analysis of composite after $\mathrm{Pb}$ (II) sorption

\begin{tabular}{|l|c|c|}
\hline \multicolumn{1}{|c|}{ Element } & Wt.\% & At. \% \\
\hline $\mathrm{NK}$ & 2.70 & 7.35 \\
\hline $\mathrm{OK}$ & 32.76 & 77.62 \\
\hline $\mathrm{AlK}$ & 1.83 & 2.57 \\
\hline $\mathrm{Ca} \mathrm{K}$ & 1.25 & 1.18 \\
\hline $\mathrm{Fe} \mathrm{K}$ & - & - \\
\hline $\mathrm{PbM}$ & 58.34 & 10.67 \\
\hline $\mathrm{AuM}$ & 3.1 & 0.30 \\
\hline Totals & 100.0 & \\
\hline
\end{tabular}

Table4: EDX analysis of composite after Cu (II) sorption

\begin{tabular}{|l|c|c|}
\hline \multicolumn{1}{|c|}{ Element } & Wt.\% & At. \% \\
\hline N K & 5.89 & 9.1 \\
\hline O K & 58.99 & 79.82 \\
\hline Al K & - & - \\
\hline Ca K & 3.61 & 1.96 \\
\hline Fe K & - & - \\
\hline Cu K & 24.51 & 8.35 \\
\hline Au M & 6.98 & 0.77 \\
\hline Totals & 100 & \\
\hline
\end{tabular}

Table 5 EDX analysis of composite after Cd (II) sorption

\begin{tabular}{|l|c|c|}
\hline \multicolumn{1}{|c|}{ Element } & Wt. \% & At. \% \\
\hline N K & 15.9 & 18.78 \\
\hline O K & 59.39 & 61.43 \\
\hline Al K & 0.6 & 0.37 \\
\hline Ca K & 2.72 & 1.12 \\
\hline Fe K & - & - \\
\hline Cd L & 9.09 & 1.34 \\
\hline Au M & 12.31 & 16.96 \\
\hline Totals & 100 & \\
\hline
\end{tabular}


- The EDX analysis of the composite before and after metals sorption is shown in Table 2,3,4,5 respectively. It showed significant change in the nitrogen and oxygen composition of the composite after metals sorption. It revealed the role of active amine groups of $\mathrm{CH}$ and active hydroxyl groups of both $\mathrm{CH}$ and $\mathrm{AC}$ in the sorption process of the three metals by the composite. This means that, chelation of metal ions by the active groups of the composite is one of the possible mechanisms. Moreover, the decrease or disappearing of $\mathrm{Al}, \mathrm{Ca}$, and $\mathrm{Fe}$ after metals sorption explains that the ion exchange mechanism could be one of the possible mechanisms with small value.

\subsection{Batch equilibrium studies}

\subsubsection{Metal hydroxide precipitation}

Figure 4 concludes that drastic change in lead precipitation started at $\mathrm{pH}$ value of 6.0 with ratio of $20 \%$ to reach to $67 \%$ at $\mathrm{pH}$ 7.0. So that, precipitation is considered the dominant mechanism of lead removal at $\mathrm{pH} \geq 6.0$. This observation has been also confirmed by other authors (Venkatesham et.al.,2013 [34], and Cechinel et.al., 2014 [35]. While for copper the precipitation started at $\mathrm{pH} 6.5$ with ratio of $30 \%$ to reach to $46 \%$ at $\mathrm{pH} 7$. And for cadmium the precipitation started at $\mathrm{pH} 7$ with ratio of $12 \%$ to reach to $53 \%$ at $\mathrm{pH} 8$. Based on the results of this experiment, and to ensure solubility of the metals to eliminate the consequence of metal precipitation, the following experiment (effect of initial $\mathrm{pH}$ ) was carried out at $\mathrm{pH}$ values of (2.0-6.0) for lead, and (2.0-7.0) for both copper and cadmium.

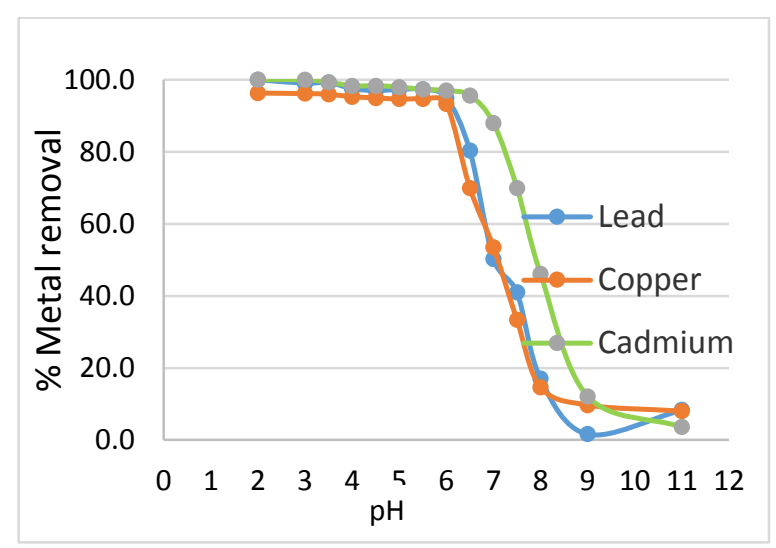

Figure4. $\mathrm{Pb}^{+2}, \mathrm{Cu}^{+2}$, and $\mathrm{Cd}^{+2}$ hydroxides precipitation as function of $\mathrm{pH}$

\subsubsection{Effect of $p H$}

Sorption of metal ions from aqueous solution is related to the $\mathrm{pH}$ of the solution, as the later affects the degree of ionization of the metal and the surface charge of the sorbent $\left(\mathrm{pH}_{\mathrm{zcp}}\right)$ [36]. Figure 5 shows that $\mathrm{CH} / \mathrm{AC}$ composite has significantly lower sorption capacity for metal uptake at $\mathrm{pH}$ below 3 . This is due to that, at low $\mathrm{pH}$ the amine groups of the chitosan in the composite get protonated. That means surface of the composite will get positive charg, and a force of repulsion will occur between the metals $\left(\mathrm{Pb}^{+2}\right.$, $\mathrm{Cu}^{+2}, \mathrm{Cd}^{+2}$ ) which have positive charge and the active sites instead of attraction.

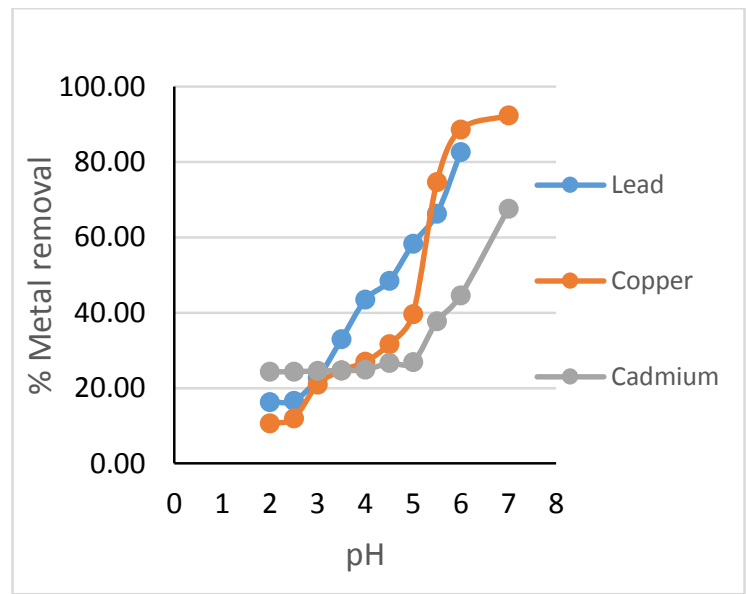

Figure5. Effect of $\mathrm{pH}$ on sorption of $30 \mathrm{mg} / \mathrm{L}$ heavy metals using $2 \mathrm{~g} / \mathrm{L}$ CH/AC composite - \% removal. 
Moreover, at lower $\mathrm{pH}$ value the solution will have more $\mathrm{H}^{+}$ions that will compete with the metal cations in the solution for binding with the active sites. At $\mathrm{pH}$ values higher than 3 , a considerable jump

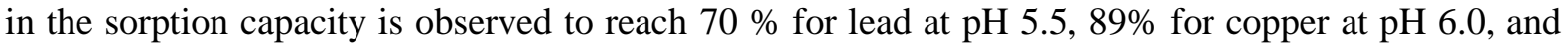
$44 \%$ for cadmium at $\mathrm{pH}$ 6.0. Further increase in the $\mathrm{pH}$ value lead to more increase in the \% removal of the three metals, however this increment is basically being related to the precipitation of the metal ions, as the metals $(\mathrm{Pb}, \mathrm{Cu}, \mathrm{Cd})$ tend to form insoluble $\mathrm{M}(\mathrm{OH})_{2}$ form at higher $\mathrm{pH}$. So that, the optimum $\mathrm{pH}$ values were revised to 5.5 for lead, and 6.0 for both copper and cadmium. The metal uptake capacity; $\mathrm{q}$ (mg metal/gram composite) at these $\mathrm{pH}$ values are $10,13.3,6.7 \mathrm{mg} / \mathrm{g}$ for lead, copper, and cadmium respectively. As the optimum $\mathrm{pH}$ of the three target metal is less than the $\mathrm{pHzcp}$ of the composite, the electrostatic interaction (physisorption) between the metal ions $\mathrm{M}^{+2}$ and the surface of the composite could be hard, and other mechanism (chemisorption) could be work as a dominant mechanism between $\mathrm{M}^{+2}$ ions and the active groups on the composite surface.

\subsubsection{Effect of contact time}

Figure 6 shows that the rate of metal sorption is rapid during the first 5 minutes to reach to $30 \%, 29 \%, 21 \%$ for lead, copper, and cadmium respectively in the first 5 minutes. After then, the removal capacity of the composite increases slowly until reaches its breakthrough of its sorption capacity (qe) after approximately 240 minutes, at which the sorption capacity reaches to $12.2 \mathrm{mg} / \mathrm{g}$ with \% removal of $81 \%$ for lead, $13.1 \mathrm{mg} / \mathrm{g}$ with \& removal of $87 \%$ for copper, and $10.4 \mathrm{mg} / \mathrm{g}$ with \% removal of $69 \%$ for cadmium. Generally, the fast sorption capacity at first 5 minutes could be attributed to physical sorption particularly with the effect of $\mathrm{AC}$ or /and the ion exchange with the elements in the composite (as shown in EDX analysis), and the slow rate at later stage attributed to chemical complexation with the active sites of the chitosan in the composite.

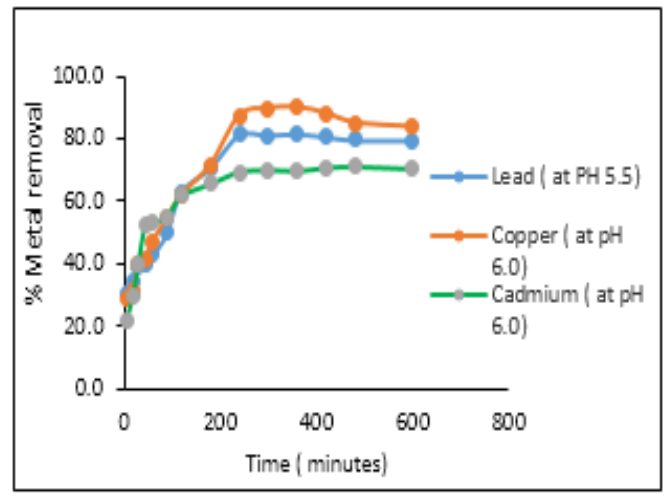

Figure 6: Effect of contact time on sorption of $30 \mathrm{mg} / \mathrm{L}$ heavy metals using $2 \mathrm{~g} / \mathrm{LCH} / \mathrm{AC}$ composite - $\%$ removal

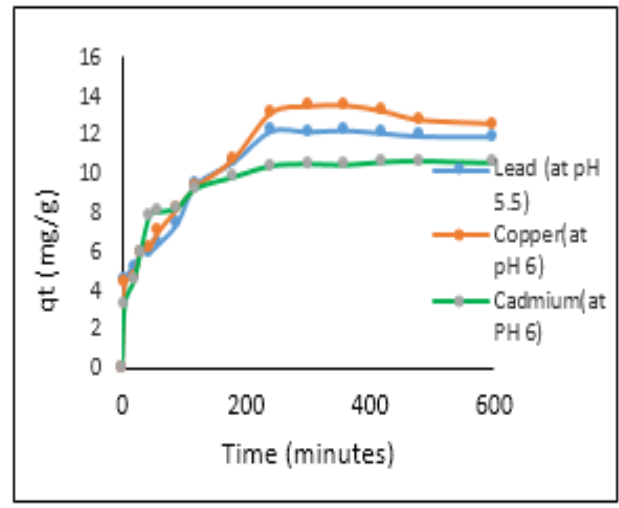

Figure 7 : qt and qe of $30 \mathrm{mg} / \mathrm{L}$ heavy metals using $2 \mathrm{~g} / \mathrm{LCH} / \mathrm{AC}$ composite.

\subsubsection{Effect of sorbent dose}

Figure 8 shows that, increasing of composite dose from [ $0.5 \mathrm{gm} / \mathrm{L}$ to $3.0 \mathrm{gm} / \mathrm{L}$ in case of $\mathrm{Pb}$, and $\mathrm{Cd}$ and to $2.5 \mathrm{gm} / \mathrm{L}$ in case of $\mathrm{Cu}$, results in dramatically increase in the percentage uptake of the metals. After then, further increasing in the composite dose leads to decrease in the $\%$ uptake. However, the specific uptake; q (mg/g) shows reverse trend at the same time. This might be attributed to that the sorption system should have an equilibrium in the ratio of sorbent / sorbate. 


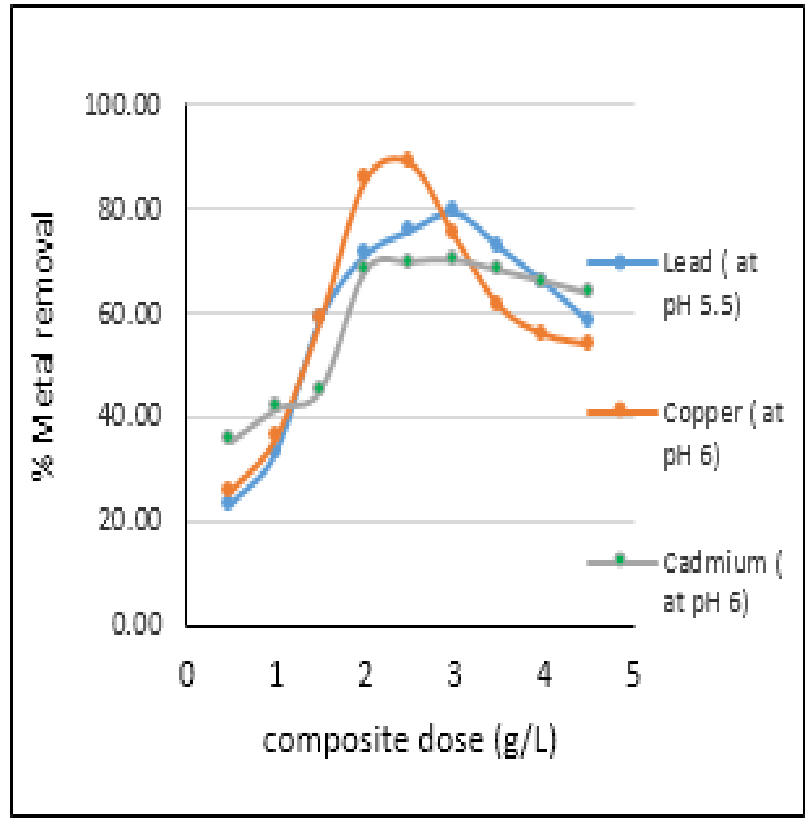

Figure 8: Effect of $\mathrm{CH} / \mathrm{AC}$ composite dose on sorption of $30 \mathrm{mg} / \mathrm{L}$ heayy metals, for $4 \mathrm{hrs}$ - \% removal.

\subsubsection{Effect of initial metal concentration}

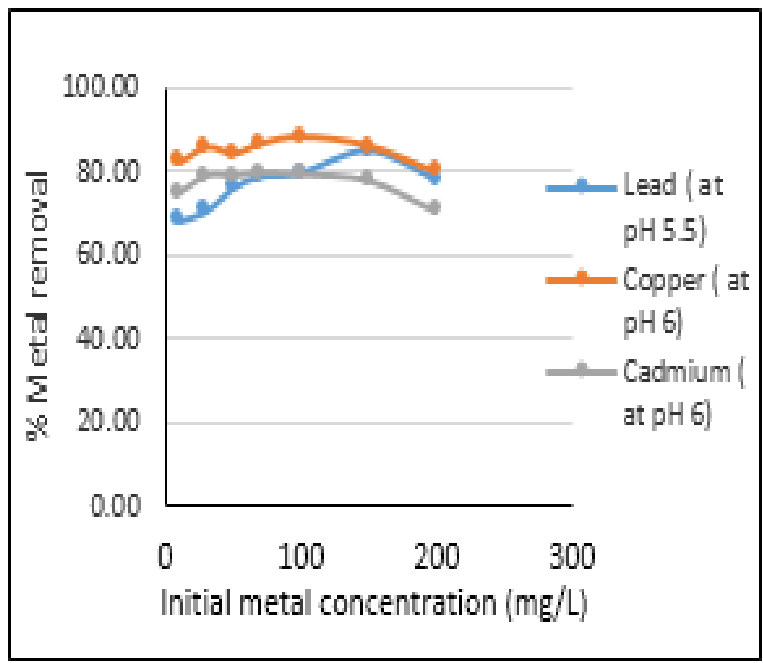

Figure 9: Effect of initial metal concentration on sorption of heavy metals, for $4 \mathrm{hrs}-\%$ removal.

Figure 9 shows that, percentage of metals uptake and the specific uptake; $\mathrm{q}(\mathrm{mg} / \mathrm{g})$ increase by increasing the initial concentration of the metal to certain ratio in the system. After then, more increase in the metal concentration leads to decrease in the percentage uptake, however the specific uptake; $q$ $(\mathrm{mg} / \mathrm{g})$ still increase. Decreasing in the percentage of metal uptake by increasing the metal concentration after certain ratio might be attributed to that, increasing of metal concentration result in establishing of completion between the metal ions to bind with the limited number of active sites on the sorbent.

\subsection{Sorption isotherm models}

\subsubsection{Langmuir \& Frendlich isotherm models}

Application of adsorption isotherms indicated that the adsorption isotherm of (lead, copper, and cadmium) by the composite is correlated well with the Langmuir type. Which revealed the possibility of chemisorption mechanism as a dominant mechanism in this process. The small value of $b$ in Langmuir model and the high value of $1 / n$ in Freundlich model indicate that, the affinity or the bond strength between the metals and the active sites of the composite is weak which makes the desorption process easier. 


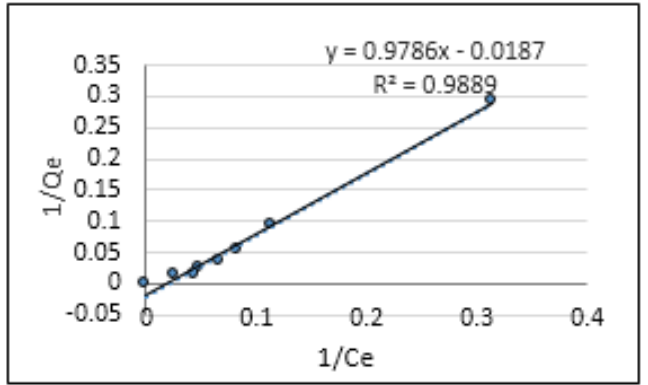

Figure 10: Langmuir isotherm model for sorption of $\mathrm{Pb}$ (II) by $\mathrm{CH} / \mathrm{AC}$ composite at $22 \pm 0.5^{\circ} \mathrm{C}$

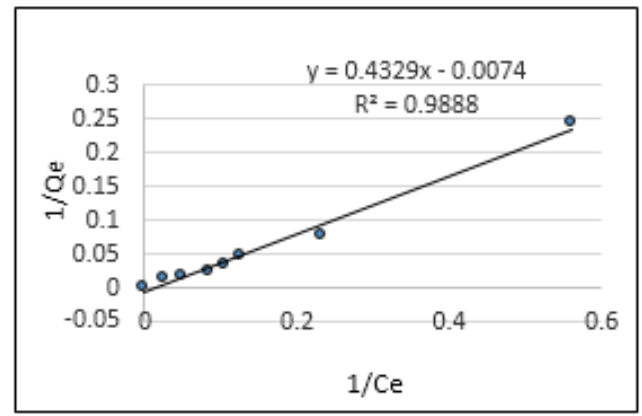

Figure 11: Langmuir isotherm model for sorption of $\mathrm{Cu}$ (II) by $\mathrm{CH} / \mathrm{AC}$ composite at $22 \pm 0.5^{\circ} \mathrm{C}$

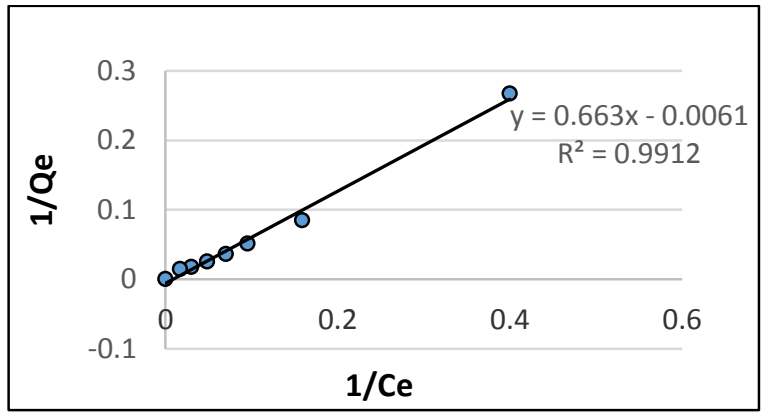

Figure 12: Langmuir isotherm model for sorption of $\mathrm{Cd}$ (II) by $\mathrm{CH} / \mathrm{AC}$ composite at $22 \pm 0.5{ }^{\circ} \mathrm{C}$

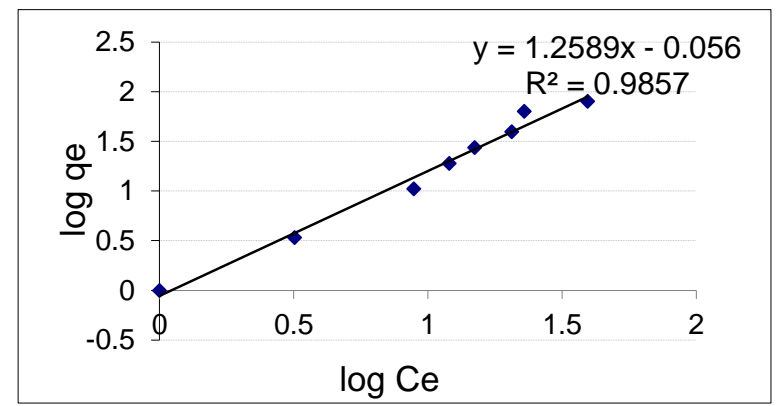

Figure 13: Freundlich isotherm model for sorption of $\mathrm{Pb}$ (II) by $\mathrm{CH} / \mathrm{AC}$ composite at $22 \pm 0.5{ }^{\circ} \mathrm{C}$

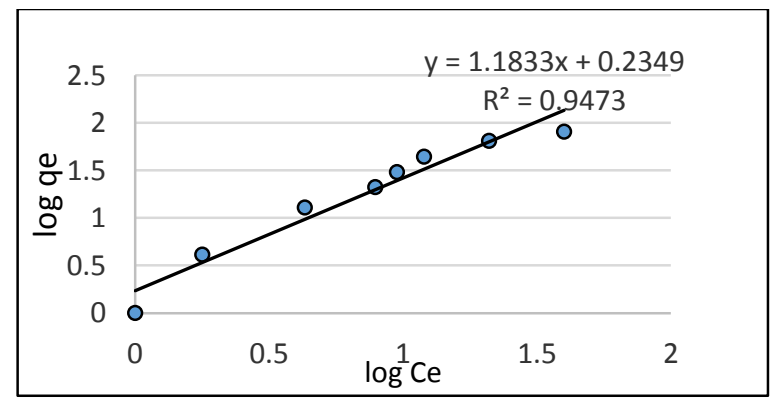

Figure 14: Freundlich isotherm model for sorption of $\mathrm{Cu}$ (II) by $\mathrm{CH} / \mathrm{AC}$ composite at $22 \pm 0.5^{\circ} \mathrm{C}$ 


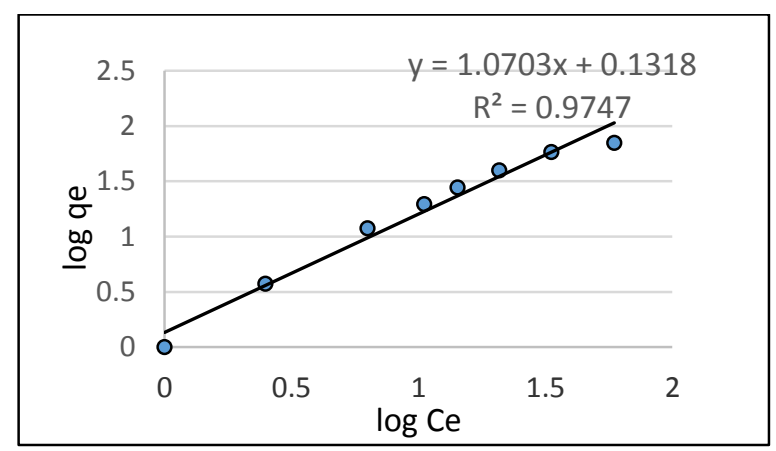

Figure 15: Freundlich isotherm model for sorption of $\mathrm{Cd}$ (II) by $\mathrm{CH} / \mathrm{AC}$ composite at $22 \pm 0.5^{\circ} \mathrm{C}$

Table 6.: Langmuir isotherm model parameters for sorption of $\mathrm{Pb}$ (II), $\mathrm{Cu}$ (II), and $\mathrm{Cd}$ (II) by $\mathrm{CH} / \mathrm{AC}$ composite at $22 \pm 0.5^{\circ} \mathrm{C}$

\begin{tabular}{|c|c|c|c|}
\hline Metal & $\mathbf{R}^{\mathbf{2}}$ & $\mathbf{b}$ & $\mathbf{Q}_{\max }$ \\
\hline $\mathrm{Pb}$ ( II) & 0.9889 & 0.019 & 53.47 \\
\hline $\mathrm{Cu}$ (II) & 0.9888 & 0.017 & 135.1 \\
\hline $\mathrm{Cd}$ (II) & 0.991 & 0.009 & 163 \\
\hline
\end{tabular}

Table 7: Freundlich isotherm model parameters for sorption of $\mathrm{Pb}$ (II), $\mathrm{Cu}$ (II), and $\mathrm{Cd}$ (II) by CH/AC composite (at $22 \pm 0.5^{\circ} \mathrm{C}, \mathrm{C}_{0} 30.0 \mathrm{mg} / \mathrm{L}$ )

\begin{tabular}{|c|c|c|c|}
\hline Metal & $\mathrm{R}^{2}$ & $1 / \mathrm{n}$ & $\mathrm{K}_{F}$ \\
\hline $\mathrm{Pb}(\mathrm{II})$ & 0.985 & 0.794 & 0.879 \\
\hline $\mathrm{Cu}$ (II) & 0.947 & 0.84 & 1.71 \\
\hline $\mathrm{Cd}$ (II) & 0.974 & 0.93 & 1.35 \\
\hline
\end{tabular}

\subsection{Sorption kinetic models}

\subsubsection{Pseudo $1^{\text {st }}$ order\& Pseudo $2^{\text {st }}$ order kinetic}

Results in Tables 8 and 9 indicates that, the value of qe (experimental) does not agree with the qe (calculated) that was deduced from pseudo-first order model. This means that the applicability to employ pseudo-first order model in the sorption process of ( $\mathrm{Pb}$ (II), $\mathrm{Cu}$ (II), and $\mathrm{Cd}$ (II)) onto $\mathrm{CH} / \mathrm{AC}$ composite is infeasible. While, the value of qe (experimental) is quite closer to qe (calculated) that was deduced from pseudo-second order kinetic model. Also, the correlation coefficient $\left(\mathrm{R}^{2}\right)$ in pseudosecond order model is close to the unity. Hence, it can be concluded that, the adsorption of ( $\mathrm{Pb}$ (II), Cu (II), and $\mathrm{Cd}$ (II)on CH/AC composite follow the pseudo-second order kinetic model. So, it can be considered that, the rate-limiting factor might be chemisorption involving valance forces through sharing of electrons between the amino groups of chitosan and the metal ions.

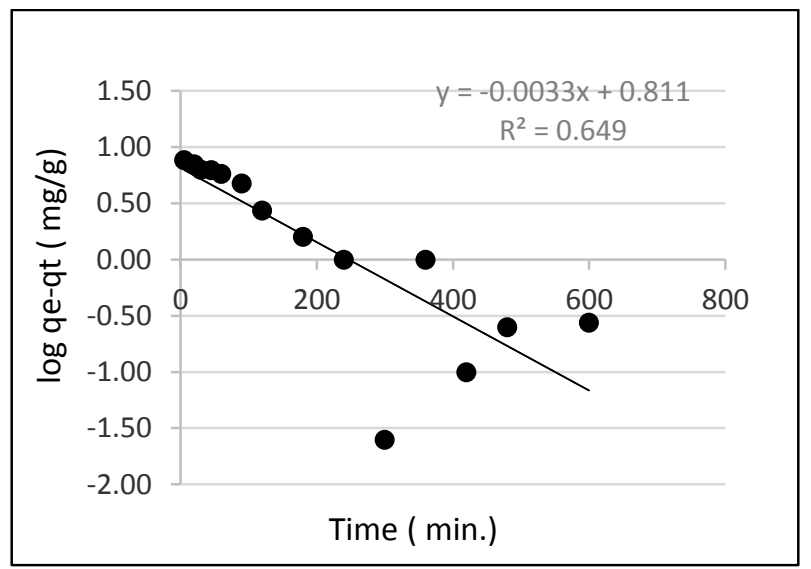

Figure 16: Pseudo first order kinetic plot of $\mathrm{Pb}$ (II) sorption by $\mathrm{CH} / \mathrm{AC}$ composite (at $22 \pm 0.5^{\circ} \mathrm{C}, \mathrm{C}_{0}=30 \mathrm{mg} / \mathrm{L}$ ) 
Equilibrium and Kinetics studies for Removal of Heavy Metals from simulated Wastewater using Chitosan/Activated carbon composite

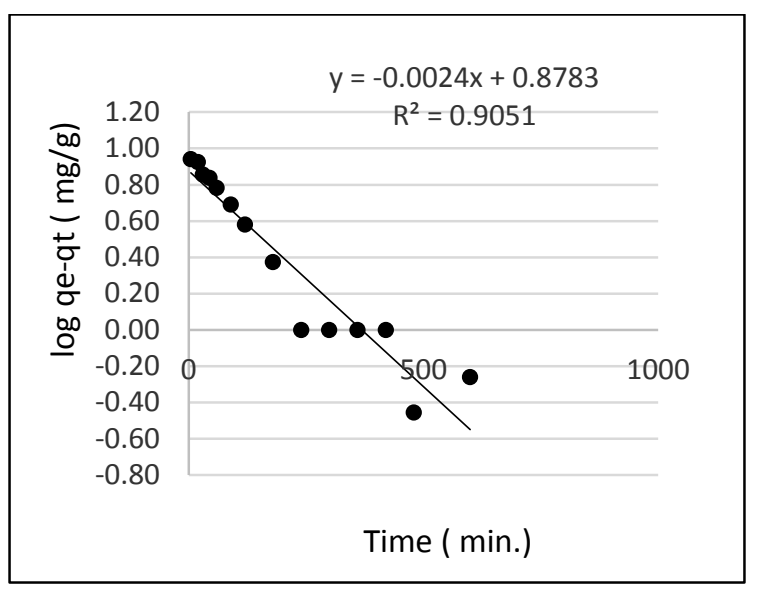

Figure 17: Pseudo $1^{\text {st }}$ order kinetic plot of $\mathrm{Cu}$ (II) sorption by $\mathrm{CH} / \mathrm{AC}$ composite (at $22 \pm 0.5{ }^{\circ} \mathrm{C}, \mathrm{C}_{0}=30 \mathrm{mg} / \mathrm{L}$

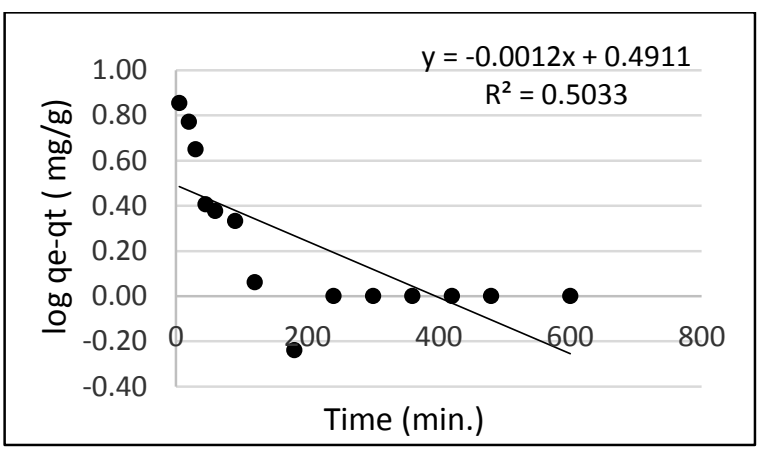

Figure 18: Pseudo first order kinetic plot of $\mathrm{Cd}$ (II) sorption by $\mathrm{CH} / \mathrm{AC}$ composite (at $22 \pm 0.5^{\circ} \mathrm{C}, \mathrm{C}_{0}=30 \mathrm{mg} / \mathrm{L}$ )

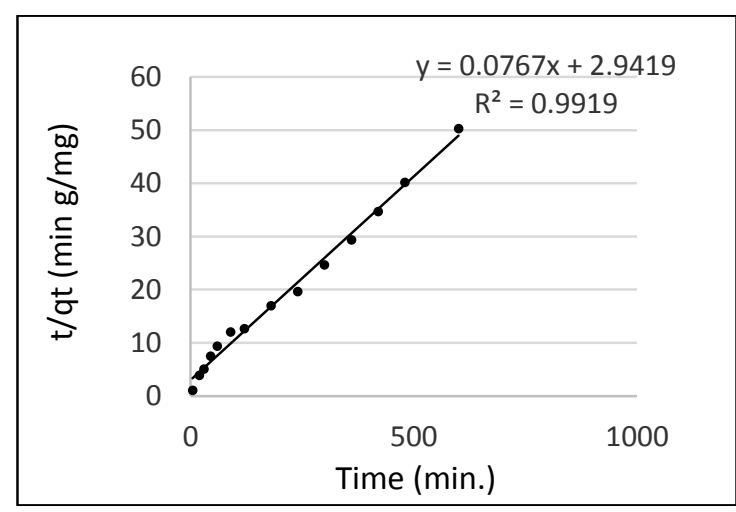

Figure 19: Pseudo $2^{\text {nd }}$ order kinetic plot of $\mathrm{Pb}$ (II) sorption by $\mathrm{CH} / \mathrm{AC}$ composite (at $22 \pm 0.5^{\circ} \mathrm{C}, \mathrm{C}_{0}=30 \mathrm{mg} / \mathrm{L}$ )

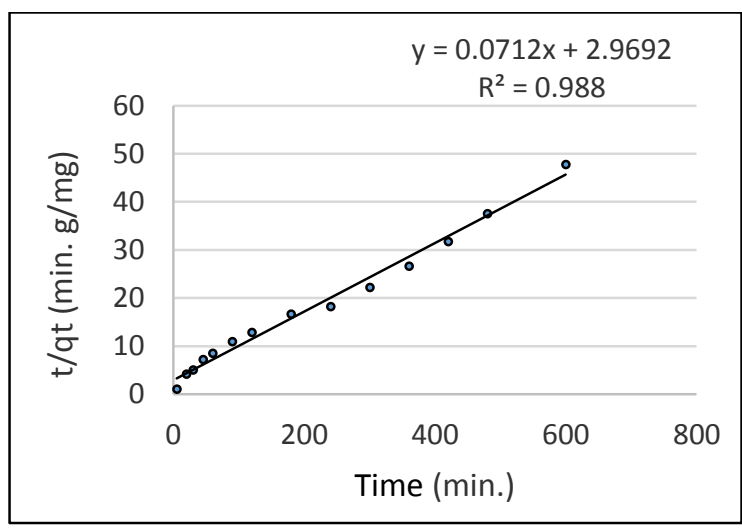

Figure 20: Pseudo second order kinetic plot of $\mathrm{Cu}$ (II) sorption by $\mathrm{CH} / \mathrm{AC}$ composite (at $22 \pm 0.5^{\circ} \mathrm{C}, \mathrm{Co}=30 \mathrm{mg} / \mathrm{L}$ ) 


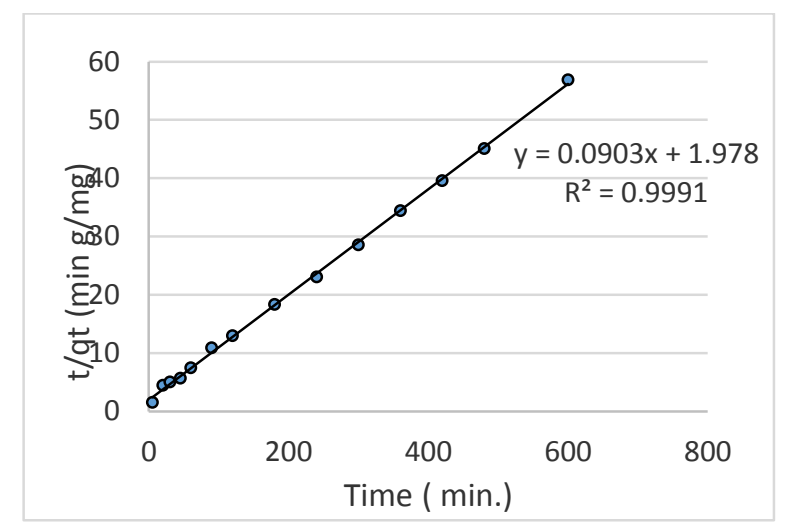

Figure 21: : Pseudo second order kinetic plot of $\mathrm{Cd}(\mathrm{II})$ sorption by $\mathrm{CH} / \mathrm{AC}$ composite (at $22 \pm 0.5{ }^{\circ} \mathrm{C}, \mathrm{C}_{0}=$ $30 \mathrm{mg} / \mathrm{L}$ )

Table 8: Pseudo first order rate constants for sorption of $\mathrm{Pb}$ (II), $\mathrm{Cu}$ (II), and $\mathrm{Cd}$ (II) by $\mathrm{CH} / \mathrm{AC}$ composite (at $22 \pm 0.5^{\circ} \mathrm{C}, \mathrm{C}_{0}=30.0 \mathrm{mg} / \mathrm{L}$ )

\begin{tabular}{|c|c|c|c|c|}
\hline Metal & $\begin{array}{c}\text { Experimental } \\
\mathrm{qe}(\mathrm{mg} / \mathrm{g})\end{array}$ & $\mathrm{R}^{2}$ & $\begin{array}{c}\text { Calculated } \\
\mathrm{qe}_{\mathrm{e}}(\mathrm{mg} / \mathrm{g})\end{array}$ & $\begin{array}{c}\mathrm{K}_{1} \\
(\mathrm{~min})^{-1}\end{array}$ \\
\hline $\mathrm{Pb}(\mathrm{II})$ & 12.2 & 0.6 & 6.47 & 0.007 \\
\hline $\mathrm{Cu}$ (II) & 13.1 & 0.9 & 7.55 & 0.005 \\
\hline $\mathrm{Cd}$ (II) & 10.4 & 0.5 & 3.098 & 0.002 \\
\hline
\end{tabular}

Table 9: Pseudo 2nd order rate constants for sorption of $\mathrm{Pb}$ (II), $\mathrm{Cu}$ (II), and $\mathrm{Cd}$ (II) by $\mathrm{CH} / \mathrm{AC}$ composite (at $22 \pm 0.5^{\circ} \mathrm{C}, \mathrm{C}_{0}=30.0 \mathrm{mg} / \mathrm{L}$ )

\begin{tabular}{|c|c|c|c|c|}
\hline Metal & Expermintal & $\mathrm{R}^{2}$ & Calculated & $\mathrm{K}_{2}$ \\
& $\mathrm{qe}(\mathrm{mg} / \mathrm{g})$ & & $\mathrm{q}_{\mathrm{e}}(\mathrm{mg} / \mathrm{g})$ & $(\mathrm{g} / \mathrm{mg}$ min $)$ \\
\hline $\mathrm{Pb}$ ( II) & 12.2 & 0.9919 & 13.03 & 0.002 \\
\hline $\mathrm{Cu}$ (II) & 13.1 & 0.988 & 14.04 & 0.002 \\
\hline $\mathrm{Cd}$ (II) & 10.4 & 0.9991 & 11.07 & 0.004 \\
\hline
\end{tabular}

\section{CONCLUSiON}

Chitosan/Activated carbon composite represents a promise eco-friendly biopolymer material, as:

- Its moderate bulk density makes it a suitable polymeric material for using in the industrial wastewater treatment plants.

-It has significant removal efficiency for the common toxic heavy metals in the wastewater; $\quad(\mathrm{Pb}, \mathrm{Cu}$, Cd).

- It can be successfully used as effective, low cost sorbent material and as alternative to costlier sorbent polymers.

- It gives a highest removal efficiency at $\mathrm{pH}$ close to the $\mathrm{pH}$ of the wastewater (5.5 for lead and 6.0 for Copper and cadmium), which reduce the need for chemical addition

- The sorption process of the three metals was fitted well with Langmuir isotherm model and pseudo second order kinetic model

-Chemisorption by chelation via making coordinate bond between the free electron pairs (of the nitrogen of the amine group, as well as the oxygen of the hydroxyl group) in chitosan and the void orbital of the metal cations is the dominant mechanism. 
Equilibrium and Kinetics studies for Removal of Heavy Metals from simulated Wastewater using Chitosan/Activated carbon composite

-However, the physical adsorption and ion exchange are possible mechanisms by small participation.

-Presence of activated carbon improve the chitosan activity by increasing its surface area.

\section{REFERENCES}

[1] T.A.H. Nguyen, H.H. Ngo, W.S. Guo, J. Zhang, S. Liang, Q.Y. Yue, Q, Li, T.V. Nguyen (2013). Applicability of agricultural waste and by-products for adsorptive removal of heavy metals from wastewater. Bioresource Technology, 148, pp 574-585, (2013).

[2] Othman, Za, Hashim, M., and Habila, Ma. (2011) "Kinetic, equilibrium and thermodynamic studies of cadmium (II) adsorption by modifies agricultural wastes" Molecules 16 (12): 10443-10456

[3] Fenglian Fu, Qi Wang. (2011). Removal of heavy metal ions from wastewaters: A review. Journal of environmental management. 92 407-418.

[4] Kupper, T., D. Burge, H.J. Bachmann, S.Gusewell, and J. Mayer (2014) "Heavy metals in source- separated compost and digestates" Waste Management 34: 867-874

[5] Lenntech, Heavy metals http:// lenntech.com /heavymetals.htm (12 December 2013)

[6] Mohsen Arbab, Sara Hemati, Masoud Amiri. (2015). Removal of lead ions from industrial wastewater: A review of removal methods. International journal of epidemiologic research. 2: 105-109.

[7] M. Soundarrajan, T. Gomathi, P.N. Sudha. (2013). Understanding the adsorption efficiency of chitosan coated carbon on heavy metal removal. International journal of scientific and research publications. 2250-3153.

[8] Jianlong Wang, Can Chen. (2014). Chitosan- based biosorbents: Modification and application for biosorption of heavy metals and radionuclides. Journal of bioresource technology 160: 129-141.

[9] World Health Organization (2011). Guidelines for drinking - water quality, fourth edition (2011). https://www.who.int/water_sanitation_health/publications/drinking-water-quality-guidelines-4-including-1staddendum/en/

[10] Coulibaly Lacina, G. Germain, and A.N. Spiros. (2003). Utilization of fungi for biotretment of raw wastewater. African Journal of Biotechnology. Vol. 2, No. 12, pp. 620-630.

[11] M. Gavrilescu. (2004). Removal of heavy metals from the environment by Biosorption. Engineering in Life Sciences. Vol. 4, No. 3, pp. 219-232

[12] T.A.H. Nguyen, H.H. Ngo, W.S. Guo, J. Zhang, S. Liang, Q.Y. Yue, Q, Li, T.V. Nguyen (2013). Applicability of agricultural waste and by-products for adsorptive removal of heavy metals from wastewater. Bioresource Technology, 148, pp 574-585, (2013).

[13] Natalya, T.V.Ramachandra, and R.D.Kanamadi. (2003). Biosorption of heavy metals. Research Journal of Chemistry and Environment.Vol. 7, No. 4, pp.71-79

[14] Rani Gupta, P. Ahuja, S.Khan, R.K.Saxena, and H.Mohapatra., (2000). Microbial Biosorbents: Meeting Challenges of Heavy metal

[15] Józef Synowiecki, and Nadia Ali Al-Khateeb (2003). Critical review in food science and nutrition, 43 (2): 145-171 (2003).

[16] Rayane Santa Cruz Martins, and Bianca Rosa Paschoal (2017). Preparation and characterization of chitosan obtained from shells of shrimp (Litopenaeus vannamei boone). Journal of marine drugs, (2017), 15,141.

[17] Christian Schmitz, Lilian González Auza, David Koberidze, Stefan Rasche, Rainer Fischer, and Luisa Bortesi (2019). Conversion of Chitin to Defined Chitosan Oligomers: Current Status and Future Prospects. Journal of Marine Drugs, 17, 452; (2019).

[18] Marguerite Rinaudo (2006). Chitin and chitosan: properties and applications. Journal of Progress in polymer science, (2006), volume 31, issue 7, pp 603-632.

[19] W.S. Wan Nagah, A. Kamari, and Y. J. Koay (2004). Equilibrium and kinetics studied of adsorption of copper (II) on chitosan and chitosan /PVA beads. International journal of biological macromolecules, vol.34: 155-0161.

[20] Jianlong Wang, and Can Chen. (2014). Chitosan- based biosorbents: Modification and application biosorption of heavy metals and radionuclides. Journal of bioresource technology 160: 129-141, 2014.

[21] Ashfaq Ahmad, Hassan Mohammed Al-Swaidan* and Ahmad Hamed Alghamdi (2015). Production of Activated Carbon from Raw Date Palm Fronds by ZnCl2 Activation. J.Chem.Soc.Pak. Vol.37, No. 06, 2013.

[22] Hakimeh Sharfifard, Farzin Zokaee Ashtiani, Mansooreh Soleimani. (2012). Adsorption of palladium and platinum from aqueous solutions by chitosan and activated carbon coated with chitosan. Asia-Pacific Journal of chemical engineering, vol. 8, pp:384-395, 2012.

[23] Viorica Patrulea, Anamaria Negrulescu, Manuela M. Mincea, Laura D. Pitulice, Otilia Bizerea Spiridon, and Vasile Ostafea,(2013). Optimization of the Removal of Copper(II) Ions from Aqueous Solution on Chitosan and Cross-Linked Chitosan Beads. Journal of bioresources 8 (1), 1147-1165; 2013. 
Equilibrium and Kinetics studies for Removal of Heavy Metals from simulated Wastewater using Chitosan/Activated carbon composite

[24] Xiaoyu Chen and Lindun He, (2017). Microwave irradiation assisted preparation of chitosan composite microsphere for dye adsorption. International journal of polymer science, volume 2017, article ID 2672597, 8 pages; 2017.

[25] H.Sharififard, M.Nabavinia, M.Soleimani (2016). Evaluation of adsorption efficiency of activated carbon/chitosan composite for removal of $\mathrm{Cr}$ (VI) and Cd (II) from single and bi-solute dilute solution. Advanced in environmental technology $4,2016$.

[26] Elisee Nsimba Bakatula, Dominique Richard, Carmen Mihaela Neculita and Gerald J. Zagury (2018). Determination of point of zero charge of natural organic materials. Journal of Environmental Science and Pollution Research, 25, pp:7823-7833, 2018.

[27] W.S. Wan Ngah, L.C.Teong, R.H.Toh, M.A.K.M. Hanafiah, (2012). Utilization of chitosan-zeolite composite in the removal of $\mathrm{Cu}$ (II) from aqueous solution: Adsorption, desorption, and fixed bed column studies. Chemical engineering journal ,209(2012),

[28] Jude C. Igwe, Augustin A. Abia, 2007. Equilibrium sorption isotherm studies of $\mathrm{Cd}(\mathrm{II}), \mathrm{Pb}(\mathrm{II})$ and $\mathrm{Zn}(\mathrm{II})$ ions detoxification from waste water using unmodified and EDTA-modified maize husk. Electronic Journal of Biotechnology, Vol. 10 No. 4, Issue

[29] Rodriguez CE, Quesada A, Rodriguez E (2006) Nickel biosorption by Acinetobacter baumannii and Pseudomonas aeruginosa isolated from industrial wastewater. Brazil Journal of microbiology 37:465-467, 2006.

[30] Sarma , P, Kumar, R. \& Pakshirajan, K. 2015 Batch and continuous removal of copper and lead from aqueous solution using cheaply available agriculture waste materials. International Journal of Environmental Research 9 (2),635-648

[31] Mambo Moyo, Linda Chikazaza, Benias Chomunorwa Nyamunda, and Upenyu Guyo (2013). Adsorption batch studies on the removal of Pb (II) using Maiz Tassel based activated carbon. Vol. 2013, article ID 508934, 8 pages.

[32] Qiqi Ding and Xijun $\mathrm{Hu}$ (2019). Mesoporous Materials as Catalyst support for WastewaterTreatment.Madridge.Journal of Nanotechnology \& Nanoscience. June 18, 2019, ISSN: 2638-2075.

[33] Asha H. Gedam and Rajendra S. Dongre (2015). Adsorption characterization of $\mathrm{Pb}$ (II) ions onto iodate doped chitosan composite: equilibrium and kinetic studies. Journal of royal society of chemistry (RSC Advances), 5: 54188-54201, 2015.

[34] Venkatesham, V., G.M.Madhu, S.V. Satyanarayana, and H.S.Preetham (2013) "Adsorption of lead on gel combustion derived nano ZnO” Procedia Engineering, 51: 308-313, 2013.

[35] Cechinel, M.A., S.M. Souza, and A.A. Souza (2014) "Study of lead (II) adsorption onto activated carbon originating from cow bone" Journal of Cleaner Production 65: 342-349. 2014.

[36] Pitsari, S.,E., Tsoufakis, and M.Loizidoi, (2013). Enhanced lead adsorption by unbleached newspaper pulp modified with citric acid. Chemical Eng. journal, 223, 18-30,2013.

Citation: Ahmed Saad Ali, et.al., " Equilibrium and Kinetics studies for Removal of Heavy Metals from simulated Wastewater using Chitosan/Activated carbon composite", International Journal of Research in Environmental Science (IJRES), vol. 6, no. 4, pp. 12-27, 2020. Available: DOI: http://dx.doi.org/ 10.20431 /2454-9444.0604002

Copyright: (C) 2020 Authors. This is an open-access article distributed under the terms of the Creative Commons Attribution License, which permits unrestricted use, distribution, and reproduction in any medium, provided the original author and source are credited. 